ECONOMIC THEMES (2019) 57(4): 511-526

DOI 10.2478/ethemes-2019-0029

\title{
THE REVIEW OF METHODS FOR ASSIGNMENT OF ELECTIVE COURSES AT UNIVERSITIES
}

\author{
Dejan Trifunović
}

University of Belgrade, Faculty of Economics, Republic of Serbia

$\bowtie$ dejan@ekof.bg.ac.rs

\begin{abstract}
UDC
378.016

Abstract: In this paper we present a review of matching algorithms that are used for matching students with elective courses at universities. This is an example of a market where price mechanism cannot be used to determine the equilibrium allocation. In the Random Serial Dictatorship students select courses based on their position in a random queue. This mechanism

Review is not ex post Pareto-efficient and its drawback is overcome in the paper Probabilistic Serial Assignment, although this mechanism is not strategyproof. In the auction mechanism, students' bids for courses do not represent their true preferences, since bids depend on their beliefs about the popularity of courses. The efficient allocation is obtained when Deferred Acceptance Algorithm is used - where the priority of students is determined based on their bids. Harvard draft mechanism is based on changing the order of students in the random queue from one round to another and this mechanism is not strategy-proof; however, it is, by all means, better for students than Random Serial Dictatorship. The Wharton Business School mechanism is based on the calculation of approximate competitive equilibrium.
\end{abstract}

Received:

Keywords: Random serial dictatorship, probabilistic serial assignment, 11.05.2019

Accepted: auctions, deferred acceptance algorithm, Harvard draft mechanism, Wharton business school mechanism.

\section{Introduction}

It is well-known fact that market prices serve to adjust supply and demand. However, in some markets the price mechanism cannot be used due to legal or ethical constraints, but the optimal allocation still needs to be determined. One may wonder: how we can imagine a market without prices? There are indeed such markets, for example, in matching students with public secondary schools that are financed by 
the government. This market has the demand side, represented by students and their preferences and the supply side, represented by schools and their capacities. If one school is popular and highly demanded by students, it cannot increase the tuition fees to reduce the demand, since tuition fees are paid by the government. In such a market, we need another approach to determine the optimal allocation.

This approach is based on the result from cooperative game theory that aims to determine the core of a cooperative game that results in the same allocation as in the competitive equilibrium with the price mechanism. In matching students and schools, we need an algorithm that mimics the market mechanism and determines the core of a cooperative game.

The first algorithm of this kind was proposed by Gale \& Shapely (1962). Lloyd Shapely was awarded a Nobel Prize in economics in 2012, along with Alvin Roth for their contributions to matching models. Shapely proposed Deferred Acceptance Algorithm that works in the following fashion. In the first step each student applies to the best school according to his preferences. Schools rank students according to priorities, e.g. the students who have brothers or sisters in the same school have a higher priority or, for example, the students who live close to the school. The school considers all the applications, tentatively retains the students with the highest priority and rejects all others. Students that are rejected apply to the second-best school in the second round. Schools consider all the applications from both rounds, then retain students with the highest priority and reject others. The students who were rejected apply to the third-best school and so on. The algorithm iterates until there are no more rejections. At that point, students are finally matched with the school they were previously retained. This algorithm implements stable allocation, which means that it is not possible to find schools and students who are not matched, and who prefer each other to the student (school) that was assigned to them in the algorithm. Nevertheless, in the US and in many other countries, the highly inefficient Boston algorithm was used. In this algorithm, in each round, schools matched with students, and that was a complicated game for both students and their parents. They were supposed to submit strategic preferences, such that they had a high probability to be enrolled in the school that had been stated as their first choice, but that school didn't necessarily have to be their true best choice. Abdulkardiroğlu, Pathak \& Roth (2005a), (2005b), (2009) identified this problem and proposed DA algorithm that considerably improved the stability of matching in the market and minimised the number of students that had to be administratively enrolled in the school that had not been stated in their preference list ${ }^{1}$.

The other important application of the DA algorithm was in matching doctors on internship (who do not receive a market-based salary during the internship) and hospitals. The hospitals wanted to secure the best students by sending early proposals to students, giving them only a short period to accept the offer. Roth \& Peranson

${ }^{1}$ For more details about matching students and schools see Trifunović (2017a). 
(1989) and Roth (1986) have proposed DA algorithm that reduced the congestion in this market and implemented stable allocation.

The two previous cases were examples of two-sided matching, where agents on each side of the market have preferences over agents on the other side of the market. In one-sided matching, only agents on the one side of the market have preferences over agents on the other side of the market. One example of such market is organ transplantation, where it is forbidden, for ethical reasons, to sell organs in the market. In this case, patients have preferences over donors (that are medically determined by the same blood group and the same tissue type), but organs do not have preferences over patients. The high mortality rate caused by the impossibility to find a compatible donor was a real problem in the market. The problem was solved by Roth, Sönmez and Unver $(2004,2007)$ who proposed the Top Trading Cycles and Chains algorithm that was based on exchanges between incompatible pairs to maximize the number of possible transplantations. The result of the application of this algorithm was a significant reduction of the mortality rate $^{2}$.

Other successful applications of matching algorithms in one-sided matching are in matching students with dormitories, where students have preferences over rooms, but rooms do not have preferences over students. The algorithm that was applied by Abdulkadiroğlu \& Sönmez (1998) takes into consideration the problem of existing tenants who are guaranteed to keep the existing room and they can obtain even better room in the algorithm.

In this paper we will study the problem of matching students and elective courses at universities. This is also one-sided matching, since only students have preferences over courses. Moreover, this is a problem of many to many matching, since a student can be matched with many courses and a course can be matched with many students. We will analyse several assignment mechanisms and their features for this purpose.

The rest of the paper is organized as follows. In the second part we present Random Serial Dictatorship that induces preference revelation, but is not ex ante Pareto-efficient. In the third part, Probabilistic Serial Assignment is presented that is ex ante Pareto-efficient, but does not induce truthful preference revelation. We will see in the fourth part that auction mechanism is not efficient due to non-monotonic relationship between preferences and bids. Deferred Acceptance Algorithm that is discussed in the fifth part is much better solution. In the sixth part we discuss Harvard Business School mechanism that is based on reversing the order of students in the random queue for course selection from one round to another. The seventh part introduces an alternative approach for the course allocation that is based on calculating approximate competitive equilibrium.

\footnotetext{
${ }^{2}$ For more details about organ transplantation see Trifunović (2017b).
} 


\section{Random serial dictatorship}

One mechanism that can be used to allocate elective courses to students is Random Serial Dictatorship (RSD). In this mechanism, students are ordered in a random queue and each student chooses a bundle of courses when it is his turn to make a choice. In RSD, students reveal their true preferences, since they cannot gain anything by misrepresenting their preferences. RSD mechanism is ex post Paretoefficient, but not ex ante (Abdulkadiroğlu \& Sönmez, 1998, Erdil, 2014, Hugh-Jones et al., 2014).

We can illustrate this mechanism with the following example, where we have 3 students $s_{1}, s_{2}, s_{3}$ and 3 courses $c_{1}, c_{2}, c_{3}$. Each course has one seat and each student chooses one course. Preferences of students are given in the following table.

Table 1 Preferences

\begin{tabular}{|c|c|c|}
\hline$\succ_{S_{1}}$ & $\succ_{S_{2}}$ & $\succ_{S_{3}}$ \\
\hline$c_{2}$ & $c_{2}$ & $c_{1}$ \\
\hline$c_{3}$ & $c_{1}$ & $c_{2}$ \\
\hline$c_{1}$ & $c_{3}$ & $c_{3}$ \\
\hline
\end{tabular}

Source: author's example

The order of students in the queue is randomly determined. Each student chooses the best course from the set of available courses. Therefore, we have 6 possible orders that are represented in the following table.

Table 2 Orders in RSD algorithm

\begin{tabular}{||l|l|l|l||}
\hline Order & $s_{1}$ & $s_{2}$ & $s_{3}$ \\
\hline$s_{1}, s_{2}, s_{3}$ & $c_{2}$ & $c_{1}$ & $c_{3}$ \\
\hline$s_{1}, s_{3}, s_{2}$ & $c_{2}$ & $c_{3}$ & $c_{1}$ \\
\hline$s_{2}, s_{1}, s_{3}$ & $c_{3}$ & $c_{2}$ & $c_{1}$ \\
\hline$s_{2}, s_{3}, s_{1}$ & $c_{1}$ & $c_{2}$ & $c_{3}$ \\
\hline$s_{3}, s_{1}, s_{2}$ & $c_{2}$ & $c_{3}$ & $c_{1}$ \\
\hline$s_{3}, s_{2}, s_{1}$ & $c_{3}$ & $c_{2}$ & $c_{1}$ \\
\hline
\end{tabular}

Source: author's example

Each order occurs with probability $1 / 6$. The deterministic assignment that is obtained for one particular random order can be represented by a matrix where rows represent students, and columns courses. For example, the first order can be represented in the following fashion: 


$$
\begin{aligned}
& \begin{array}{l}
s_{1} \\
s_{2} \\
s_{3}
\end{array}\left[\begin{array}{lll}
0 & 1 & 0 \\
1 & 0 & 0 \\
0 & 0 & 1
\end{array}\right] . \\
& \begin{array}{llll}
c_{1} & c_{2} & c_{3}
\end{array}
\end{aligned}
$$

Each matrix represents the deterministic assignment for one realization of random order. When we multiply the deterministic assignment for one random order with the probability of its occurrence and sum up these matrices, we obtain the random assignment in RSD algorithm:

$$
\begin{gathered}
\frac{1}{6}\left[\begin{array}{lll}
0 & 1 & 0 \\
1 & 0 & 0 \\
0 & 0 & 1
\end{array}\right]+\frac{1}{6}\left[\begin{array}{lll}
0 & 1 & 0 \\
0 & 0 & 1 \\
1 & 0 & 0
\end{array}\right]+\frac{1}{6}\left[\begin{array}{lll}
0 & 0 & 1 \\
0 & 1 & 0 \\
1 & 0 & 0
\end{array}\right]+\frac{1}{6}\left[\begin{array}{lll}
1 & 0 & 0 \\
0 & 1 & 0 \\
0 & 0 & 1
\end{array}\right]+\frac{1}{6}\left[\begin{array}{lll}
0 & 1 & 0 \\
0 & 0 & 1 \\
1 & 0 & 0
\end{array}\right]+\frac{1}{6}\left[\begin{array}{lll}
0 & 0 & 1 \\
0 & 1 & 0 \\
1 & 0 & 0
\end{array}\right]= \\
=\frac{1}{6}\left[\begin{array}{lll}
1 & 3 & 2 \\
1 & 3 & 2 \\
4 & 0 & 2
\end{array}\right] .
\end{gathered}
$$

Therefore, the course allocation in RSD algorithm results in the following random assignment:

$$
\begin{aligned}
& \begin{array}{l}
s_{1} \\
s_{2} \\
s_{3}
\end{array}\left[\begin{array}{ccc}
1 / 6 & 1 / 2 & 1 / 3 \\
1 / 6 & 1 / 2 & 1 / 3 \\
2 / 3 & 0 & 1 / 3
\end{array}\right] . \\
& \begin{array}{lll}
c_{1} & c_{2} & c_{3}
\end{array}
\end{aligned}
$$

This random assignment is ex post efficient, which means that there is no other feasible allocation in which all students are weakly better off and some students are strictly better off. However, this assignment is not ex ante Pareto-efficient, since students could be made better off if they are allowed to trade probabilities of obtaining certain courses. For example, student $s_{1}$ would like to trade with $s_{3}$ and reduce the probability of obtaining course $c_{1}$, which is his the least preferred course, and $s_{3}$ would like to increase the probability of obtaining the course $c_{1}$ which is his the most preferred course.

\section{Probabilistic serial assignment}

The mechanism that achieves ex ante Pareto-efficiency is called Probabilistic Serial Assignment (PS) and was constructed by Bogomolnaia \& Moulin $(2001,2002)$. In 
this algorithm (also called Simultaneous eating algorithm), that has a time dimension from 0 to 1 , each student starts "eating" its favourite course at the constant unit speed which is the same for all students. Since in our example each course has one seat, when the course is eaten up, a student starts eating his second most preferred course and so on. The algorithm is finished when the clock reaches $t=1$.

In our example, $s_{1}$ and $s_{2}$ start "eating" their most preferred course, $c_{2}$ and $s_{3}$ start "eating" their most preferred course $c_{1}$ at $t=0$. At $t=1 / 2$ the capacity of $c_{2}$ is eaten up, and $s_{1}$ and $s_{2}$ have "eaten" $1 / 2$ of $c_{2}$ and $s_{3}$ has also "eaten" $1 / 2$ of course $c_{1}$. At $t=1 / 2$, $s_{1}$ starts "eating" its second-best course $c_{3}, s_{2}$ starts "eating" its second-best course $c_{1}$ and $s_{3}$ continues "eating" its most preferred course $c_{1}$. At $t=3 / 4$ course $c_{1}$ is "eaten up" and $s_{3}$ has "eaten" $3 / 4$ of the course, $s_{2}$ has "eaten" $1 / 4$ of the course $c_{1}$ and $s_{1}$ has "eaten" $1 / 4$ of $c_{3}$. At $t=3 / 4 s_{1}$ continues "eating" $c_{3}$ and $s_{2}$ and $s_{3}$ start "eating" their third best choice $c_{3}$. At $t=1, c_{3}$ is no longer available and $s_{1}$ has "eaten" $1 / 2$ of $c_{3}$, and $s_{2}$ and $s_{3}$ have both "eaten" $1 / 4$ of $c_{3}$.

We can interpret the quantities "eaten" by students as the probabilities of obtaining a course and we have the following stochastic assignment matrix:

$$
\begin{aligned}
& \begin{array}{l}
s_{1} \\
s_{2} \\
s_{3}
\end{array}\left[\begin{array}{ccc}
0 & 1 / 2 & 1 / 2 \\
1 / 4 & 1 / 2 & 1 / 4 \\
3 / 4 & 0 & 1 / 4
\end{array}\right] . \\
& \begin{array}{lll}
c_{1} & c_{2} & c_{3}
\end{array}
\end{aligned}
$$

This PS random assignment represents Pareto improvement compared to RSD assignment. Student $s_{1}$ obtains his most preferred course $c_{2}$ with the same probability in both mechanisms $(1 / 2)$, his second-best choice $c_{3}$ with higher probability in PS $(1 / 2)$ than in RSD (1/3), and his third best choice $c_{1}$ with lower probability in PS (0) than in RSD (1/6). Student $s_{2}$ obtains his most preferred course $c_{2}$ with the same probability in PS and RSD (1/2), his second-best choice $c_{1}$ with higher probability in PS (1/4) than in RSD (1/6), and his third best choice $c_{3}$ with lower probability in PS (1/4) than in RSD (1/3). Student $s_{3}$ obtains his most preferred course $c_{1}$ with higher probability in PS (3/4) than in RSD (2/3), his second-best choice $c_{2}$ with the same probability in PS (0) and in RSD (0), and his third best choice $c_{3}$ with lower probability in PS (1/4) than in RSD (1/3). Therefore, the stochastic assignment PS first-order stochastically dominates RSD assignment which means that PS ex ante Pareto dominates RSD.

It should be also added that RSD is strategy-proof and not ex ante Paretoefficient, while PS is not strategy-proof, but it is ex ante Pareto-efficient. The result that PS is not strategy-proof was proved by Bogomolnaia \& Moulin (2001). In the experiment conducted by Hugh-Jones et al. (2014) the misrepresentation of preferences in PS for strategic students was based on switching positions of the two most preferred courses. 
In large markets, where the number of courses increases, Che \& Kojima (2010) prove that RSD assignment converges to PS assignment. However, in the problem of allocation of elective courses, the result of convergence is not expected to hold due to the limited number of elective courses.

\section{Auction mechanism}

The system that was applied for allocation of elective courses at some universities was based on auction mechanism. Students obtain certain number of points that represent their budget constraint and they can submit bids for elective courses up to the budget. Students with the highest bids, up to the course capacity, are matched with the course. The implicit assumption of this mechanism is that bids represent preferences, For example, the higher bid for course $c_{1}$ than for course $c_{2}$ implies that a student prefers $c_{1}$ to $c_{2}$. However, bid depends on preferences, but also on the student's beliefs about course popularity. Even though the student prefers course $c_{1}$ to course $c_{2}$, he may submit higher bid for $c_{2}$ than for $c_{1}$, if he believes that course $c_{2}$ is more popular and that he will, even with a lower bid, obtain a seat in $c_{1}$. Therefore, auction mechanism is not incentive compatible and results in an inefficient allocation, which we will illustrate in the example below.

We will illustrate how the auction mechanism works, based on the modified example from Sönmez \& Ünver (2010). We have 3 students that should choose one course and 3 courses with one seat. Each student has 11 points for bid submission. The utility of courses for students is given in the following Table, where $\varepsilon$ is a small number.

Table 3 Utility of courses for students

\begin{tabular}{||c|c|c|c||}
\hline \hline$u$ & $c_{1}$ & $c_{2}$ & $c_{3}$ \\
\hline$s_{1}$ & 0 & 10 & $10-\varepsilon$ \\
\hline$s_{2}$ & 10 & 0 & $10-\varepsilon$ \\
\hline$s_{3}$ & 10 & $10-\varepsilon$ & 0 \\
\hline
\end{tabular}

Source: Sönmez \& Ünver (2010)

Suppose that students have the following beliefs about the probability that the market clearing price for the course is equal 10. The market clearing price is the lowest accepted bid for the course. 
Table 4 Students' beliefs

\begin{tabular}{|c|c|}
\hline$\pi$ & $p=10$ \\
\hline$c_{1}$ & 0,6 \\
\hline$c_{2}$ & 0,7 \\
\hline$c_{3}$ & 0,8 \\
\hline
\end{tabular}

Source: Sönmez \& Ünver (2010)

The student bids 10 for one of the two most preferred courses, and between the two, for the course with higher probability, that market price are equal to 10. For the second course between the two most preferred courses, the student bids 1 . This is a Bayesian game where bid is based on the student's preferences and beliefs. For example, for the student $s_{1}$, the two most preferred courses are $c_{2}$ and $c_{3}$, and the probability that the market price equals 10 is higher for $c_{3}$ and he bids 10 for this course and bids 1 for $c_{2}$. The bids of other students are determined in the same fashion and we have the following table with bids.

Table 5 Students' bids (1)

\begin{tabular}{|c|c|c|c||}
\hline$b$ & $c_{1}$ & $c_{2}$ & $c_{3}$ \\
\hline$s_{1}$ & 0 & 1 & 10 \\
\hline$s_{2}$ & 1 & 0 & 10 \\
\hline$s_{3}$ & 1 & 10 & 0 \\
\hline
\end{tabular}

Source: Sönmez \& Ünver (2010)

In the case of tied bids, a lottery assigns a random number to each student's bid to break ties. Suppose that a student $s_{1}$ draws random number 0,3 , a student $s_{2} 0,1$ and a student $s_{3} 0,2$. When we add these random numbers to bids, we obtain the following table with bids.

Table 6 Students' bids (2)

\begin{tabular}{|c|c|c|c|}
\hline$b$ & $c_{1}$ & $c_{2}$ & $c_{3}$ \\
\hline$s_{1}$ & 0 & 1,3 & 10,3 \\
\hline$s_{2}$ & 1,1 & 0 & 10,1 \\
\hline$s_{3}$ & 1,2 & 10,2 & 0 \\
\hline
\end{tabular}

Source: Sönmez \& Ünver (2010)

The highest bid for course $c_{1}$ is 1,2 and this course is allocated to the student $s_{3}$. The top bid for course $c_{2}$ is 10,2 and this course goes to $s_{3}$ and course $c_{3}$ goes to $s_{1}$. Since $s_{3}$ is matched with two courses and he prefers $c_{1}$, the course $c_{2}$ will be allocated to $s_{2}$. We have the following allocation in the auction mechanism: 


$$
\left(\begin{array}{lll}
c_{1} & c_{2} & c_{3} \\
s_{3} & s_{2} & s_{1}
\end{array}\right) .
$$

The overall level of utility achieved by 3 students is $20-\varepsilon$, where $s_{1}$ has utility of $10-\varepsilon, s_{2}$ has utility of 0 , and $s_{3}$ has utility of 10 .

\section{Deferred acceptance algorithm}

To achieve an efficient allocation, Sönmez \& Ünver (2010) have proposed Deferred Acceptance (DA) algorithm that works in the following fashion. Students submit their preferences over courses and also submit bids for each course subject to the budget constraint, determined by the number of points they have. Bids serve to determine priorities of students for courses, such that the student with the highest bid has the highest priority and so on. Students are also constrained by the number of courses they need to choose and each course has the maximum number of seats.

Each course tentatively accepts students with the highest bids (with the highest priorities) who have applied for this course. The lottery is used to tie-break equal bids. The students who were rejected propose to the second-best courses on their preference list. Each course considers all the applications from both rounds and tentatively keeps students with the highest priority (highest bids) up to its capacity and rejects others. The algorithm proceeds iteratively until there are no more rejections. In this algorithm students submit true preferences, but bids are still determined strategically.

We will illustrate DA mechanism on the example from Table 3. In the first step, each student applies to its top choice: $s_{2}$ and $s_{3}$ apply to $c_{1}$ and $s_{1}$ applies to $c_{2}$.

Table 7 DA algorithm (1)

\begin{tabular}{|c|c|c|}
\hline$c_{1}$ & $c_{2}$ & $c_{3}$ \\
\hline $\mathbf{s z}_{2}, S_{3}$ & $S_{1}$ & \\
\hline
\end{tabular}

Source: Author

According to the priorities based on bids (Table 6), $c_{1}$ rejects $s_{2}$ and keeps $s_{3}$. In the next step, $s_{2}$ applies to his second-best choice $c_{3}$ and we have the final matching.

Table 8 DA algorithm (2)

\begin{tabular}{|c|c|c|}
\hline$c_{1}$ & $c_{2}$ & $c_{3}$ \\
\hline$s 3$ & $s 1$ & $s 2$ \\
\hline
\end{tabular}

Source: Author 
The overall level of utility achieved by 3 students is $30-\varepsilon$, where $s_{1}$ has utility of $10, s_{2}$ has utility of $10-\varepsilon$, and $s_{3}$ has utility of 10 . Compared to the auction mechanism, $s_{3}$ is indifferent and other two students are better off in DA algorithm. Therefore, DA algorithm is a Pareto improvement to the auction mechanism.

\section{Harvard business school mechanism}

Harvard draft algorithm is a version of a Random Serial Dictatorship where the order in the queue is reversed from one round to another. This algorithm is used at Harvard Business School (HBS) based on the following procedure.

In the first step, students submit true or strategic preference list for elective courses. In the second step, a random number is drawn that determines the order of serial dictators (the order of a student in the queue for choosing the courses). In the third step and in each odd step, respecting the order of random numbers and starting with the student with the highest random number, students who have not yet filled the necessary number of courses are assigned the most preferred course among the courses with empty seats. In the fourth step and in each even step, the order of the queue is reversed, so that the student with the lowest random number that has not yet filled the necessary number of courses is assigned the most preferred course among the courses with empty seats, the student with the second lowest number is assigned the most preferred course among the courses with empty seats and so on.

If we have 3 students $s_{1}, s_{2}, s_{3}$, and if the students are assigned random lottery numbers $3,1,5$, in each odd round the order in the queue is $s_{3}, s_{1}, s_{2}$, while in each even round the order in the queue is $s_{2}, s_{1}, s_{3}$.

The most important feature of the Harvard draft mechanism is that it is not strategy-proof, since students have an incentive to put higher on their preference list a course that is popular, if this does not reduce the probability of obtaining truly the most preferred course.

We will illustrate how this algorithm works based on the example from Haeringer (2017). Suppose that there are 3 students $s_{1}, s_{2}, s_{3}$ that need to select 2 courses, and 4 courses $c_{1}, c_{2}, c_{3}, c_{4}$ with 2 available seats. Preferences of the students are given in the following table.

Table 9 Preferences

\begin{tabular}{||c|c|c||}
\hline$\succ_{S_{1}}$ & $\succ_{S_{2}}$ & $\succ_{S_{3}}$ \\
\hline$c_{1}$ & $c 2$ & $c 1$ \\
\hline$c_{2}$ & $c 1$ & $c 3$ \\
\hline$c_{3}$ & $c 3$ & $c 4$ \\
\hline$c_{4}$ & $c 4$ & $c 2$ \\
\hline
\end{tabular}

Source: Haeringer, (2017) 
We will first analyse the case when students submit true preferences in the first step. In the second step, the position in the random queue is determined. In the third step, $s_{2}$ certainly obtains one seat at $c_{2}$, regardless of his order in the queue, since other students demand $c_{1}$. In the fourth round, $c_{1}$ is not available, it has filled the seats in the previous round and the courses that are still available are $c_{2}$ with one seat and $c_{3}, c_{4}$ with 2 seats. In the fourth round, $c_{2}$ is assigned to $s_{1}, c_{3}$ is assigned to $s_{2}$, and also $c_{3}$ is assigned to $s_{3}$. Therefore, if $s_{2}$ submits true preferences, he is assigned courses $\left(c_{2}, c_{3}\right)$.

We will next analyse the case when $s_{2}$ submits strategic preferences, so that he puts the popular course $c_{1}$ in the first place and his submitted preferences are $c_{1}, c_{2}$, $c_{3}, c_{4}$. Other students submit true preferences.

In the third round, $c_{1}$ is assigned to $s_{2}$ if he is the first or the second in the random queue and the joint probability of this event is $2 / 3$. In the fourth round, there are no more empty seats at $c_{1}$, there is one empty seat in $c_{2}$ if $s_{1}$ was at the bottom of the queue in the previous round and two empty seats at $c_{3}$ and $c_{4}$. If $s_{3}$ was at the bottom of the queue in the previous round, there is one empty seat in $c_{3}$ and 2 seats in $c_{2}$ and $c_{4}$. If the available seats in the fourth round are one empty seat in $c_{2}$ and 2 seats at $c_{3}$ and $c_{4}, s_{1}$ is assigned $c_{3}, s_{2}$ is assigned $c_{2}$ and $s_{3}$ is assigned $c_{3}$. If the available seats in the fourth round are one empty seat in $c_{3}$ and 2 seats at $c_{2}$ and $c_{4}, s_{1}$ is assigned $c_{2}$, $s_{2}$ is assigned $c_{2}$ and $s_{3}$ is assigned $c_{4}$. In any case, $s_{2}$ obtains one seat at $c_{2}$.

If $s_{1}$ is the last in the random queue in the third round, which occurs with probability $1 / 3$, he is assigned $c_{2}$ in the third round. Since the order of the queue is reversed in the fourth round, $s_{1}$ will choose the first in that round and he obtains $c_{3}$.

Therefore, if $s_{2}$ submits true preferences, he obtains courses $\left(c_{2}, c_{3}\right)$. On the other hand, if $s_{2}$ is strategic, he obtains courses $\left(c_{2}, c_{3}\right)$ with probability $1 / 3$ and courses $\left(c_{1}, c_{2}\right)$ with probability $2 / 3$. Thus, by submitting strategic preferences, $s_{2}$ cannot be made worse off and can only be made better off. This example illustrates that Harvard draft mechanism is not incentive compatible.

The properties of HBS were studied by Budish \& Cantillon (2012). As the previous example shows, the mechanism is not incentive compatible and there are two sorts of preference manipulation. First, students increase the ranking of popular courses in their preference list relative to true preferences, in order not to miss the opportunity to obtain these courses. Second, there is a strategic risk taking, since students decrease the ranking of unpopular courses relative to their true preferences and hope to obtain these courses in further rounds. The first type of manipulation induces congestion for popular courses, which makes students who truly prefer popular courses worse off. The second type of manipulation may reduce the welfare of students who truly prefer these courses, but may miss to obtain them due to the underreporting. 
These strategies of manipulation were formalized by Budish \& Cantillon (2012), stating that students should increase the ranking of popular courses if it does not cause missing truly popular courses and should not increase the ranking of popular courses if this manipulation causes missing the preferred course for sure. Furthermore, Budish and Cantillon (2012) conclude that due to these facts, HBS mechanism with equilibrium strategies may be ex post inefficient and all students prefer the set of courses they obtain, when all students submit true preferences to the set of courses, they obtain with equilibrium strategies. In reality, students also make strategic mistakes which reduce their welfare furthermore.

In the following discussion, Budish \& Cantillon (2012) conduct empirical analysis, based on the data about choices of MBA students at Harvard Business School (HBS) in 2005-2006. In May, the students were invited to submit true preferences over courses, and these data were used to adjust course capacities. After that, there was a trial run and students were informed about oversubscribed courses. The real run was conducted in July. The comparison of the data from May and July reveals strategic behaviour predicted by the theory. The courses that had been oversubscribed in the trial run had higher demand in July than in May and courses that had been unpopular in the trial run had lower demand in July. However, changes in preferences were also identified, and some students that had ranked some courses in top 5 in May, had not ranked those courses in the preference list in July. There were also strategic mistakes stemming from students' incorrect beliefs about the popularity of some courses.

The data also reveal that more students were worse off due to the strategic preference submission, than the number of students who benefited from strategic play. In the strategic HBS, 64 percent of students could trade between themselves to reach Pareto improvement. On the other hand, in HBS with true preference submission, there were no such Pareto-improving exchanges. In fact, the distribution of course assignments in the truthful HBS first-order stochastically dominated the distribution of course assignments in the strategic HBS. In the truthful HBS, 82 percent of students were matched with their favorite course and in the strategic HBS 63 percent. Also, students obtained 2.46 of their three favorite courses in a truthful HBS, and 1.99 of their three favorite courses in a strategic HBS.

Since HBS is not incentive compatible, Budish \& Cantillon (2012) compare it with RSD mechanism that is incentive compatible. In this mechanism students are randomly ordered and they select the entire bundle of courses when it is their turn to select. However, RSD is a risky lottery for students and if students are risk averse, they prefer HBS to RSD. Even if students are risk neutral, they prefer HBS to RSD. This result stems from the fact that the distribution of course assignments in strategic HBS first-order stochastically dominates the distribution of course assignments in RSD, since RSD distribution puts more mass on the tails of the distribution. In the strategic HBS, 63 percent of students obtain their favorite course, and only 49 
percent in RSD. Therefore, truthful HBS is better for students than strategic HBS, which is in turn better than RSD.

Finally, Budish \& Cantillon (2012) modify HBS in the following fashion to obtain a strategy-proof mechanism that is called the Proxy draft. Students submit preference list to a proxy who chooses strategically on behalf of the students. Second, the proxy has the information on the student's position in the random queue. These two features of the mechanism alleviate strategic mistakes. The proxy can calculate the run-out time for each course and the students submit true preferences.

The data show that the distribution of course assignments in the Proxy draft firstorder stochastically dominates the distribution of course assignments in the strategic HBS, but the distribution of course assignments in the Proxy draft is dominated by the truthful HBS. The average rank of bundles that students obtain in the truthful HBS is 7,66, in the Proxy draft it is 7,84, in the strategic HBS 7,99 and in RSD 8,74.

\section{The Wharton Business School Mechanism}

The mechanism for course allocation that operates in a quite different way than the Proxy draft was proposed by Budish (2011). The method calculates approximate equilibrium prices for courses. The equilibrium price for the course is the lowest accepted bid. The adjective approximate relates to the fact that some courses can slightly increase the number of seats if necessary and students obtain a budget in the form of the number of points. The budget constraint can vary in the interval $+/-1.6 \%$.

The procedure that is used by Budish \& Kessler (2016) to reveal the students' preferences is conducted in two steps. In the first step, a student assigns a certain number of points (between 0 and 100), where 0 indicates that the student is not interested in the course and larger numbers indicate higher interest. In the second step, the students can update their score for a pair of courses. They can reduce the score compared to the sum of the single course scores if the two courses are substitutes and increase the score compared to the sum of the single course scores if the two courses are complements.

This procedure relies on heavy computer calculations and was conducted at Wharton business school in 2013. The oversubscription was not an issue of concern, since only 11 courses had to slightly increase the capacity. Students preferred the set of courses allocated in the approximate equilibrium to the set of courses obtained in the auction mechanism and this procedure clearly increased efficiency. The justified envy was also reduced in the approximate equilibrium, compared to the auction mechanism. 


\section{Conclusion}

In this paper, we have presented the algorithms for assignment of elective courses to students at universities. The unexpected result in this many-to-many matching models is that the mechanism that is incentive compatible can be dominated by a mechanism without this property. This is a quite unexpected result, since one of the objectives of the matching models is to assure incentive compatibility.

RSD is a very simple mechanism where students submit true preferences, but it is not ex ante Pareto efficient. PS algorithm is, in contrast, ex ante Pareto efficient, but it is not incentive compatible. The auction mechanism is a complicated Bayesian game where students bid strategically. The outcome of the auction mechanism is dominated by DA algorithm where students submit true preferences over courses and their bids determine their priorities for the courses. HBS is a version of RSD when the order of serial dictators is reversed from one round to another. In contrast to RSD, HBS is not incentive compatible. The Wharton method is based on the calculation of the approximate competitive equilibrium.

These models can be applied only at the universities that have an upper limit for the number of students at elective courses. When such constraint does not exist, there is no scarcity on the supply side of the market and no need for the matching models.

The issue that was not discussed in the up-to-date literature is the presence of the lower limit on the number of students at elective courses. If such a constraint is imposed, it would considerably alter the construction of matching algorithms and would possibly reverse some of the conclusions concerning the desirable properties of the algorithms.

\section{References}

Abdulkadiroğlu, A. \& Sönmez, T. (1998). Random Serial Dictatorship and the Core from Random Endowments in House Allocation Problems. Econometrica, 66(3), 689-701.

Abdulkadiroğlu, A., Pathak, P. \& Roth, A. (2005a). The New York City High School Match. American Economic Review, 95(2), 364-367.

Abdulkadiroğlu, A., Pathak, P. \& Roth, A. (2009). Strategy-Proofness versus Efficiency in School Choice with Indifferences: Redesigning the NYC School Match. American Economic Review, 99(5), 1954-1978.

Abdulkadiroğlu, A., Pathak, P., Roth, A. \& Sönmez, T. (2005b). The Boston Public School Match. American Economic Review, 95(2), 368-371.

Bogomolnaia, A. \& Moulin, H. (2001). A New Solution to the Random Assignment Problem. Journal of Economic Theory, 100, 295-328.

Bogomolnaia, A. \& Moulin, H. (2002). A Simple Random Assignment Problem with a Unique Solution. Economic Theory, 19, 623-635.

Budish, E., \& Cantillon, E. (2012). The Multi-unit Assignment Problem: Theory and Evidence from Course Allocation at Harvard. American Economic Review, 102(5), 2237-71. 
Budish, E., \& Kessler, J. (2016). Bringing Real Market Participants' Real Preferences into the Lab: An Experiment that Changed the Course Allocation Mechanism at Wharton. National Bureau of Economic Research.

Budish, E. (2011). The Combinatorial Assignment Problem: Approximate Competitive Equilibrium from Equal Incomes. Journal of Political Economy, 119(6), 1061-1103.

Che, Y.-K. \& Kojima, F. (2010). Asymptotic Equivalence of Probabilistic Serial and Random Priority Mechanisms. Econometrica, 78(5), 1625-1672.

Erdil, A. (2014). Strategy-proof Stochastic Assignment. Journal of Economic Theory, 151, 146162.

Gale, D. \& Shapely, L. (1962). College Admission and the Stability of Marriage. American Mathematical Monthly, 69, 9-15.

Haeringer, G. (2017). Market Design: Auctions and Matching, MIT Press.

Hugh-Jones, D., Kurino, M. \& Vanberg, C. (2014). An Experimental Study of the Incentives of the Probabilistic Serial Mechanism. Games and Economic Behavior, 87, 367-380.

Roth, A. \& Peranson, E. (1999). The Redesign of the Matching Market for American Physicians: some Engineering Aspects of Economic Design. American Economic Review, 89(4), 748-780.

Roth, A. (1986). On the Allocation of Residents to Rural Hospitals: A General Property of Twosided Matching Market. Econometrica, 425-427.

Roth, A,, Sönmez, T. \& Ünver, U. (2004). Kidney Exchange. Quarterly Journal of Economics, 119(2), 457-488.

Roth, A., Sönmez, T. \& Ünver, U. (2007). Efficient Kidney Exchange: Coincidence of Wants in Markets with Compatibility-based Preferences. American Economic Review, 97(3), 828851.

Sönmez, T. \& Ünver, U. (2010). Course Bidding at Business Schools. International Economic Review, 51, 99-123.

Trifunović, D. (2017a). Uparivanje učenika i škola. Ekonomski horizonti, 19(2), 125-140.

Trifunović, D. (2017b). Uparivanje donora organa i pacijenata. Anali Ekonomskog fakulteta u Subotici, 38, 3-22. 


\title{
PREGLED METODA ZA DODELJIVANJE IZBORNIH PREDMETA NA UNIVERZITETIMA
}

\begin{abstract}
Apstrakt: U ovom radu prikazujemo algoritme uparivanja koji se koriste za uparivanje studenata sa izbornim predmetima na univerzitetima, što predstavlja primer tržišta na kome nije moguće koristiti cenovni mehanizam da bi bila određena ravnotežna alokacija. U algoritmu slučajne serijske diktature slučajnim putem je određen redosled studenata za izbor predmeta. Ovaj mehanizam nije ex post Pareto efikasan, pa je ovaj nedostatak otklonjen u algoritmu slučajnog serijskog dodeljivanja. Međutim, algoritam slučajnog serijskog dodeljivanja ne dovodi do istinitog navođenja preferencija. U aukcijskom mehanizmu studenti podnose ponude za predmete u vidu virtuelnih bodova, ali ove ponude ne odražavaju njihove preferencije, jer ponuda zavisi i od njihovih uverenja o popularnosti predmeta. Efikasna alokacija se dobija ako koristimo algoritam odloženog prihvatanja $u$ kome je prioritet studenata $u$ algoritmu određen na osnovu njihovih ponuda u iznosu virtuelnih bodova koje podnose $u$ aukcijskom delu mehanizma. Harvardski mehanizam je zasnovan na obrtanju slučajnog redosleda, na osnovu koga studenti biraju predmete, iz jedne iteracije u drugu. Ovaj mehanizam ne dovodi do istinitog otkrivanja preferencija, ali je bolji za studente od slučajne serijske diktature. Mehanizam sa Warton poslovne škole zasnovan je na određivanju alokacije koja približno odgovara konkurentskoj ravnoteži.
\end{abstract}

Ključne reči: slučajna serijska diktatura, slučajno serijsko dodeljivanje, aukcije, algoritam odloženog prihvatanja, Harvardski mehanizam, mehanizam Warton poslovne škole.

\section{Author's biography}

Dejan Trifunović is associate professor at the University of Belgrade, Faculty of Economics. He graduated in 2002, and completed $\mathrm{PhD}$ studies in 2009 at the Faculty of Economics in Belgrade, receiving several awards for the best undergraduate and graduate students. He obtained several scholarships for visiting EU universities (University of Nice, University of Coimbra, Tor Vergata, LUMSA). He also received Fulbright scholarship at Ohio State University (2013/14) and AUF scholarships for economic conferences in French. He teaches Microeconomics, Industrial organisation (undergraduate), Microeconomics (master, PhD) and Microeconomics in English (LSE program). He also taught Microeconomics (undergraduate) and Economic Growth (graduate) in French (joint degree with the University of Nice). He was a member of a $\mathrm{PhD}$ thesis committee at the University of Nice in French. His scientific interest is in game theory, auctions, matching, asymmetric information and network externalities. 